\title{
NTRK2 wt Allele
}

National Cancer Institute

\section{Source}

National Cancer Institute. NTRK2 wt Allele. NCI Thesaurus. Code C52189.

Human NTRK2 wild-type allele is located in the vicinity of 9q22.1 and is approximately $353 \mathrm{~kb}$ in length. This allele, which encodes BDNF/NT -3 growth factors receptor protein, plays a role in both cellular differentiation and MAPK signal transduction pathways. 